\title{
COMMENTS
}

\section{JOINT OWNERSHIP OF GOMPUTER SOFTWARE COPYRIGHT: A SOLUTION TO THE WORK FOR HIRE DILEMMA}

\section{STACY L. JARETT $\dagger$}

The definition of an "employee" who prepares a work for hire under the first subsection of the Copyright Act of 1976 (the "Act") is one of the most contested issues in the copyright field today. A split between the Second and Seventh Gircuits and the Fifth, Ninth, and District of Columbia Circuits prompted the Supreme Court to grant certiorari on the D.G. Circuit case. ${ }^{2}$ The Second ${ }^{3}$ and Seventh ${ }^{4}$ Circuits argue for an expansive definition of "employee" incorporating earlier

† B.A. 1987, J.D. Candidate 1990, University of Pennsylvania. I would like to thank Mark $\mathrm{H}$. Biddle for sparking my interest in computer law.

1 The Copyright Act of 1976, Pub. L. No. 94-553, 90 Stat. 2541 (1976) (codified as amended at 17 U.S.C. $\S \S 101-914$ (1982 \& Supp. IV 1986)), defines works made for hire as:

(1) a work prepared by an employee within the scope of his or her employment; or

(2) a work specially ordered or commissioned for use as a contribution to a collective work, as a part of a motion picture or other audiovisual work, as a translation, as a supplementary work, as a compilation, as an instructional text, as a test, as answer material for a test, or as an atlas, if the parties expressly agree in a written instrument signed by them that the work shall be considered a work made for hire.

17 U.S.C. $\S 101$ (1982). Section 201(b) discusses the ownership of works made for hire:

In the case of a work made for hire, the employer or other person for whom the work was prepared is considered the author for purposes of this title, and, unless the parties have expressly agreed otherwise in a written instrument signed by them, owns all of the rights comprised in the copyright.

Id. $\S 201(\mathrm{~b})$.

2 On November 7, 1988, the Supreme Court granted certiorari on Community for Creative Non-Violence v. Reid, 846 F.2d 1485 (D.C. Cir.), cert. granted, 109 S. Ct. 362 (1988).

${ }^{3}$ See Aldon Accessories Ltd. v. Spiegel, Inc., 738 F.2d 548, 551-52 (2d Cir.), cert. denied, 469 U.S. 982 (1984).

- See Evans Newton Inc. v. Chicago Sys. Software, 793 F.2d 889, 894 (7th Gir.), cert. denied, 479 U.S. 949 (1986). 
copyright common law. The Fifth, ${ }^{5}$ Ninth, ${ }^{6}$ and D.G. ${ }^{7}$ Gircuits maintain that Congress intended to change the definition of "work for hire" and restrict the definition of an "employee" at least to traditional agency principles. ${ }^{8}$ Although many scholars have addressed the subject, ${ }^{9}$

- See Easter Seal Soc'y for Crippled Children \& Adults of La., Inc. v. Playboy Enters., 815 F.2d 323, 329-31, 334-36 (5th Cir. 1987), cert. denied, 108 S. Ct. 1280 (1988).

- See Dumas v. Gommerman, 865 F.2d 1093, 1102 (9th Cir. 1989).

7 See Community for Creative Non-Violence v. Reid, 846 F.2d 1485, 1492-94 (D.C. Cir.), cert. granted, 109 S. Ct. 362 (1988).

8 See Restatement (Second) of Agency $§ 220$ (1958). The definition of servant states:

(1) A servant is a person employed to perform services in the affairs of another and who with respect to the physical conduct in the performance of the services is subject to the other's control or right to control.

(2) In determining whether one acting for another is a servant or an independent contractor, the following matters of fact, among others, are considered:

(a) the extent of control which, by the agreement, the master may exercise over the details of the work;

(b) whether or not the one employed is engaged in a distinct occupation or business;

(c) the kind of occupation, with reference to whether, in the locality, the work is usually done under the direction of the employer or by a specialist without supervision;

(d) the skill required in the particular occupation;

(e) whether the employer or the workman supplies the instrumentalities, tools, and the place of work for the person doing the work;

(f) the length of time for which the person is employed;

(g) the method of payment, whether by the time or by the job;

(h) whether or not the work is a part of the regular business of the employer;

(i) whether or not the parties believe they are creating the relation of master and servant; and

(j) whether the principal is or is not in business.

Id.

9 See, e.g., Gallay, Authorship and Copyright of "Works Made for Hire": Bugs in the Statutory System, 8 Colum. J. ART \& L. 573, 580 (1984) (arguing that commissioned works should be works for hire only if they are covered in the second section of the work for hire definition in the Act); Hardy, An Economic Understanding of Copyright Law's Work-Made-for-Hire Doctrine, 12 Colum.-VLA J.L. \& ARTS 181, 183 (1988) (arguing that work for hire status should be given to works when the commissioner is the better exploiter of the work); Litman, Copyright, Compromise, and Legislative History, 72 CORNELI L. REv. 857, 862 (1987) (discussing the compromises that led to the present work for hire provisions); O'Meara, "Works Made for Hire" Under the Copyright Act of 1976-Two Interpretations, 15 CREIGHTON L. Rev. 523, 537-39 (1982) (arguing that courts should give great protection to employers or commissioners of works for hire); Note, The Treatment of Computer Software Works Made for Hire Under the Copyright Act of 1976, 5 CoMPUTER L.J. 579, 592-98 (1985) [hereinafter Note, Treatment of Computer Software] (discussing various ways for computer software to be considered commissioned works of the type listed in the definition of work for hire under the Copyright Act of 1976); Comment, The "Works Made for Hire" Doctrine and the Employee / Independent Contractor Dichotomy: The Need for Congressional Clarification, 10 COMM/ENT L.J. 591, 597 (1988) [hereinafter Com- 
most discuss the effect of work for hire doctrine on artists or authors and almost entirely ignore another copyrightable form: computer software. ${ }^{10}$

Computers and the software needed to run them are an integral part of American life. They are indispensable to businesses, ${ }^{11}$ hospitals, and transportation. ${ }^{12}$ As computer use proliferates, disputes over the ownership of commissioned software will certainly increase. Computer software cases have recently appeared more frequently in the work for hire area. ${ }^{13}$ Courts should therefore consider the needs of software developers and programmers when determining the definition of work for hire.

ment, Employee/Independent Contractor Dichotomy] (calling for legislative amendments to remedy the problems with the work for hire provisions in the Copyright Act of 1976); Note, Computer Programs and Other Faculty Writings Under the Work-forHire Doctrine: Who Owns the Intellectual's Property?, 1 Santa Clara Computer \& High-Tech. L.J. 141, 142 (1985) [hereinafter Note, Faculty Writings] (arguing that the present work for hire doctrine is at odds with academic tradition of allowing faculty to keep the copyright of their works and suggesting methods to protect faculty rights); Comment, Commissioned Works as Works Made for Hire Under the 1976 Copyright Act: Misinterpretaion and Injustice, 135 U. PA. L. REv. 1281, 1282 (1987) [hereinafter Comment, Commissioned Works] (arguing that drastic legislative changes are necessary to protect the rights of authors); Note, The Works Made For Hire Doctrine Under the Copyright Act of 1976-A Misinterpretation: Aldon Accessories Ltd. v. Spiegel, Inc., 20 U.S.F. L. REv. 649, 652 (1986) [hereinafter Note, A Misinterpretation] (arguing that Aldon undermines the congressional intent to protect independent contractors, as shown by the provision of two definitions of works made for hire in the 1976 Copyright Act); Note, The Freelancer's Trap: Work for Hire Under the Copyright Act of 1976, 86 W. VA. L. REv. 1305, 1310-38 (1984) [hereinafter Note, The Freelancer's Trap] (discussing work for hire doctrine from the legislative and common law perspectives).

10 Only two pieces have appeared in law reviews since 1980 on the subject of computers and work for hire. See Note, Treatment of Computer Software, supra note 9; Note, Faculty Writings, supra note 9. Both articles are over three years old.

"II See Hafner, Is Your Computer Secure?, Bus. WEek, Aug. 1, 1988, at 64, 65 ("Every workday, U.S. computer networks transmit close to $\$ 1$ trillion among financial institutions, an amount equal to $25 \%$ of the gross national product.").

12 The 1988 estimated expenditures on computer systems and office machines are approximately $\$ 62$ billion, up from $\$ 58$ billion in 1987. See id. at 66 . Software sales account for at least one-fourth of that total. For example, by 1992 , software sales will be approximately $22 \%$ of IBM's aggregate sales. See Guterl, IBM's Very Tough Guy, Bus. Month, Feb. 1988, at 22, 25.

13 See Evans Newton Inc. v. Chicago Sys. Software, 793 F.2d 889 (7th Cir.), cert. denied, 469 U.S. 949 (1986); Hudson v. Good Rush Messenger Serv., Inc., 2 Copyright L. Rep. (CCH) 26,089 (S.D.N.Y. Apr. 16, 1987); Q-Co Indus. v. Hoffman, 625 F. Supp. 608 (S.D.N.Y. 1985); BPI Sys., Inc. v. Leith, 532 F. Supp. 208 (W.D. Tex. 1981); cf. American Directory Serv. Agency, v. Beam, No. 87-1653 (D.D.C. Mar. 28, 1988) (WESTLAW, Allfeds database) (concentrating on joint ownership of computer software without addressing whether software was a work for hire); Whelan Assocs. v. Jaslow Dental Laboratory, Inc., 609 F. Supp. 1307, 1319 (E.D. Pa. 1985) (ruling out, in a case based primarily on copyrightability of discrete parts of software, the possibility of the disputed software as a work for hire), affd on other grounds, 797 F.2d 1222 (3d Cir. 1986), cert. denied, 479 U.S. 1031 (1987). 
In Part I, this Comment will discuss the process of programming and the copyrightability of computer software. Part II will briefly review the common and statutory law of works for hire before and after the Act. Part III will discuss the concept of joint ownership of copyright. Finally, Part IV will apply the definitions of work for hire and joint ownership to computer software. This analysis will demonstrate that the Fifth, Ninth, and D.C. Circuits advance the preferable interpretation of works made for hire and that courts should increase the role of joint ownership of copyright to settle conflicts between programmers and commissioners of software.

\section{Copyrightability of Computer Software}

Software is comprised of three main parts: the logical layout of the program, usually contained in flow charts or diagrams; the source code and object code; ${ }^{14}$ and the user materials, such as manuals. Although it is well accepted that the source and object codes receive copyright protection as literary works, ${ }^{15}$ and assumed that the same is true for user manuals, ${ }^{16}$ the copyrightability of the logical layout of the program, often called the sequence, structure, and organization of the program, ${ }^{17}$ is less certain. ${ }^{18}$

In general, the organization of a program can take many forms. Thus, the programmer selects, through a particular layout, one out of many possible arrangements of the program. The Third Circuit recognized that the author contributes a great deal of creativity in designing the logical layout of a program when it said:

As the program structure is refined, the programmer must make decisions about what data is needed, where along

14 The source code is the programming done in the specific computer language, such as BASIC or COBOL. The object code is the computer-translated binary code that the computer actually understands and uses to perform the functions. See Whelan Assocs. v. Jaslow Dental Laboratory, Inc., 797 F.2d 1222, 1230-31 (3d Cir. 1986), cert. denied, 479 U.S. 1031 (1987).

15 See Apple Computer, Inc. v. Franklin Computer Corp., 714 F.2d 1240, 1249 (3d Cir. 1983), cert. dismissed, 464 U.S. 1033 (1984).

18 See Evans Newton Inc. v. Chicago Sys. Software, 793 F.2d 889, 895 (7th Cir.), cert. denied, 479 U.S. 949 (1986).

${ }_{17}$ See Whelan, 797 F.2d at 1224 n.1.

18 Compare Whelan, 797 F.2d at 1224-25 (holding that sequence, structure, and organization of software are copyrightable expressions of an idea) with Plains Cotton Coop. Ass'n v. Goodpasture Computer Serv., 807 F.2d 1256, 1262 (5th Cir. 1987) (holding that the organization of a specific program was not copyrightable) and Synercom Tech., Inc. v. University Computing Co., 462 F. Supp. 1003, 1014 (N.D. Tex. 1978) (holding that sequence, structure, and organization of software are noncopyrightable ideas). 
the program's operations the data should be introduced, how the data should be inputted, and how it should be combined with other data. The arrangement of the data is accomplished by means of data files . . . and is affected by the details of the program's subroutines and modules, for different arrangements of subroutines and modules may require data in different forms. Once again, there are numerous ways the programmer can solve the data-organization problems she or he faces. Each solution may have particular characteristics-efficiencies or inefficiencies, conveniences or quirks-that differentiate it from other solutions and make the overall program more or less desirable. ${ }^{18}$

Those who create these important facets of a computer program should receive some form of copyright protection. Unfortunately, the Second and Seventh Circuits' interpretation of work for hire could deny creators of flow charts any copyright protection.

\section{The Definition of Works Made for Hire Before the COPYRIGHT ACT OF 1976}

\section{A. The Definition Under the Copyright Act of $1909^{20}$}

Congress derives its authority for copyright protection from the direction in the copyright clause of the United States Constitution to "promote the Progress of Science and useful Arts, by securing for limited Times to Authors and Inventors the exclusive Right to their respective Writings and Discoveries . . .."21 In the 1909 Act, Congress extended copyright protection beyond the limits of traditional authorship to encourage others to foster artistic creation with a definition of author "includ[ing] an employer in the case of works for hire."22

Once Congress broadened the definition of author to include employers, courts began to expand the definition of employer from its traditional agency law meaning. In Brattleboro Publishing Co. v. Win-

19 Whelan, 797 F.2d at 1230. The Whelan opinion had its roots in an earlier district court opinion, SAS Inst., Inc. v. S \& H Computer Sys., 605 F. Supp. 816 (M.D. Tenn. 1985), that discussed the creativity involved in developing the organization of a program. See Whelan, 797 F.2d at 1239.

20 The Copyright Act of 1909, Pub. L. No. 60-349, 35 Stat. 1075 (the "1909 Act"), repealed by The Copyright Act of 1976, Pub. L. No. 94-553, 90 Stat. 2541 (codified as amended at 17 U.S.C. §§ 101-914 (1982 \& Supp. IV 1986)).

21 U.S. CoNST. art I, $\S 8$, cl. 8.

22 The Copyright Act of 1909 , Pub. L. No. 60-349, ch. 320, § 62, 35 Stat. 1075, 1088 , repealed by The Copyright Act of 1976 , Pub. L. No. 94-553, $\S 101,90$ Stat. 2541, 2544 (codified at 17 U.S.C. § 101 (1982)). 
mill Publishing Corp., ${ }^{23}$ the Second Circuit extended work for hire protection to an employer dealing with an independent contractor when the "work is produced at the instance and expense of [the] employer."24 The court further broadened the definition in Scherr $v$. Universal Match Corp. ${ }^{25}$ with a "right to control" test:

The essential factor in determining whether an employee created his work of art within the scope of his employment as part of his employment duties is whether the employer possessed the right to direct and to supervise the manner in which the work was being performed. . . . Other pertinent, but non-essential, considerations, are those indicating at whose insistence, expense, time and facilities the work was created. ${ }^{26}$

While the Brattleboro court implied that the commissioner should and actually did exercise this control to get copyright protection under work for hire, ${ }^{27}$ the Scherr court made it clear that the employer need not contribute creatively to the work. ${ }^{28}$ The "right to control" test assumes that copyright control would encourage patrons to solicit more works, thus encouraging more artists to create. By allowing artists the opportunity to obtain contractually the copyright to the work, courts attempted to balance the relationship between patron and artist. ${ }^{29}$

This theory, however, ignores the patron's greater bargaining power. Because of the presumption against the "employee," artists under the 1909 Act would automatically lose their rights to the work unless they could force the patron to transfer those rights. Unknown artists certainly would lack the economic power to compel a patron to transfer the rights: a patron can always hire another artist, but an un-

23 369 F.2d 565 (2d Gir. 1966).

24 Id. at 567-68.

25 417 F.2d 497 (2d Cir. 1969), cert. denied, 397 U.S. 936 (1970).

${ }^{28} \mathrm{Id}$. at $500-01$.

27 See Brattleboro, 369 F.2d at 567.

28 See Scherr, 417 F.2d at 500.

${ }_{28}$ See Brattleboro, 369 F.2d at 568. This was not a novel theory. See Yardley v. Houghton Mifflin Co., 108 F.2d 28, 31 (2d Cir. 1939), cert. denied, 309 U.S. 686 (1940). This case did not specifically use the work for hire theory, but it did state the basis for the 1909 Act's common law work for hire doctrine:

If [an artist] is solicited by a patron to execute a commission for pay, the presumption should be indulged that the patron desires to control the publication of copies and that the artist consents that he may, unless by the terms of the contract, express or implicit, the artist has reserved the copyright to himself.

Id. 
known artist would not be able to find another patron as easily. ${ }^{30}$ Proponents of the 1909 Act theory often argued that the commission price would include the value of these rights, making no difference to the artist if she does not retain the rights. ${ }^{31}$ The potential value of an unexposed artist's work is difficult to estimate, however, and it is even more difficult for the artist to extract a high price from the patron. As a result, artists in the 1909 Act work for hire situation would generally sell their works for very little and lose all of the rights to them. ${ }^{32} \mathrm{Al}-$ though the "right to control" test had the advantage of being relatively simple and predictable to apply because of its objectivity, it created a bargaining edge for patrons that allowed them to take advantage of artists. $^{33}$ In recognition of this inequity, the drafters of the 1976 Act attempted to change the statutory definition of works made for hire. ${ }^{34}$

30 See infra note 32.

${ }^{31}$ See Scherr, 417 F.2d at 502 (Friendly, J., dissenting) (stating that "it is not unreasonable to assume . . that the parties expected the purchaser to wind up owning the work lock, stock, and copyright and that the artist set his price accordingly").

${ }^{32}$ See, e.g., Definition of Work Made for Hire in the Copyright Act of 1976: Hearing before the Senate Comm. on the Judiciary, 97th Cong., 2d Sess. 2-4 (1982) [hereinafter Senate Hearing] (statement of Robin Brickman, Graphic Artists Guild) (telling of the financial problems she had because of her lack of bargaining power when dealing with publishing companies, and explaining that one serious inequity is that independent contractors, who get none of the benefits of regular employment, get the disadvantages of regular employment by losing the copyright to works created for the employer); id. at 5 (statement of June Roth, Pres. of the Am. Soc'y of Journalists and Authors) ("We cannot survive with one-time payments for well-researched and wellwritten articles that have future resale potential that is denied by the work for hire coercion. Yet, many writers cannot refuse to sign or not accept work; it is an ultimatum."). But see id. at 49-50 (statement of E. Gabriel Perle, Vice Pres., Time, Inc.) (stating that most publishers do not want all of these rights and the potential mistreatment of poor artists actually does not take place).

These artists were arguing that, through work for hire contracts, publishers were forcing artists to sign away the rights they presumptively owned. The situation is similar to the unequal bargaining power between the parties in the pre-Act situation. Whether the patron's superior bargaining position is used to make the artist sign away her rights or to keep her from contractually saving them, the effect is clear: artists under economic pressure lose the rights to their works without being fully compensated. See generally id. (containing statements from artists and publishers on the abuses in and misperceptions of the application of the work made for hire doctrine).

${ }^{33}$ Even some publishers testifying in the work for hire hearings in 1982 admitted that the situation under the 1909 Act gave the commissioners an unfair edge. See id. at 48 (statement of Townsend Hoopes, Pres. of Ass'n of Am. Publishers).

34 See id.; $c f .134$ Cong. Rec. S6736-37 (daily ed. May 19, 1987) (statement of Sen. Cochran) ("When Congress enacted these provisions, it intended commissioned works to be works made for hire only if the requirements of the clause (2) of this definition were met. Congress further intended that 'employee' works make for hire, which fall under clause (1) of the definition would be the product of the traditional employer-employee relationship, in which the employee would give up authorship and copyright rights in his or her creations in exchange for a regular salary and other employment benefits.") 


\section{B. Change and Compromise Under the 1976 Copyright Act}

Preparation for a new copyright act began in the $1950 \mathrm{~s}^{35}$ The fact that the Copyright Office took more than two decades to change the 1909 Copyright Act shows that the new Act was not to be a slight revision, but a drastic transformation. ${ }^{36}$ Much of the discussion during the alteration period focused on works made for hire. First, the Copyright Office requested the report made in 1958 by Borge Varmer. ${ }^{37}$ Based on this report and other input from concerned parties, a draft of the new wording was released in 1961. This draft proposed that works made for hire be "works created by an employee within the regular scope of his employment." Bs By using the terms "regular scope of his employment," the drafters attempted to limit work for hire to traditional employment relationships. ${ }^{30}$ They feared, however, that this definition would not indicate clearly enough the intended change from the 1909 Act definition. By 1963, they had refined the definition to "a work prepared by an employee within the scope of the duties of his employment, but not including a work made on special order or commission." 40

Publishers and other types of commissioning employers protested this definition. They claimed that the proposed Act, by precluding their ability to retain copyright protection for commissioned works, would also preclude their ability to create compilations and other sorts of commonly commissioned works. ${ }^{41}$ As a result, the drafters ultimately compromised with the publishing groups and allowed certain categories of commissioned works to be included in the definition of works for hire in the 1976 Act. $^{42}$ Thus, the drafters of the new Act intended only

35 See Staff of Subcomm. on Patents, Trademarks, and Copyrights of the Senate Comm. on the Judiciary, 86th Cong., 1st Sess., Copyright Law Revision 127 (Comm. Print 1960) (report by B. Varmer), reprinted in 1 STudies oN Copyright 717 (The Copyright Society of U.S.A. eds. 1963).

${ }^{36}$ See Senate Hearing, supra note 32, at 49-50 (statement of E. Gabriel Perle, Vice Pres. of Time, Inc.).

37 See supra note 35.

38 Report of the Register of Copyrights on the General, Revision of the U.S. Copyright Law, 87th Cong., 1st Sess. 87, 88 (Comm. Print 1961), quoted in LATMan's The Copyright LaW 119 (W. Patry 6th ed. 1986) [hereinafter [ATMAN].

38 See LATMan, supra note 38, at 119.

10 Id.

41 See Senate Hearing, supra note 32, at 49 (statement of Townsend Hoopes, Pres. of Ass'n of Am. Publishers).

${ }^{12}$ See H.R. ReP. No. 1476, 94th Cong., 2d Sess. 121, reprinted in 1976 U.S. Code Cong. \& Admin. News 5659, 5736 [hereinafter House REPORT] ("The workmade-for-hire provisions of this bill represent a carefully balanced compromise . . . ."); see also 17 U.S.C. $\S 101$ (1982) (providing a definition of "work made for hire"). 
certain commissioned works to be works for hire, and then only if the parties executed a written instrument conferring work for hire status on a creation." The first part of the definition, "a work prepared by an employee within the scope of his or her employment," "s4 seems, by comparison with earlier drafts of the definition and the reference to agency law, limited to the traditional employment relationship..$^{45}$ Even representatives of the publishers conceded this to be the proper interpretation. ${ }^{46}$ Unfortunately, the Second and Seventh Circuits interpret this definition with little attention to these statements, instead incorporating into the definition a modified version of the common law regarding works for hire under the 1909 Act.

\section{Cases Construing the 1976 Act}

The major appellate cases regarding work for hire take two paths. The Second and Seventh Circuits interpret the first section of the work for hire status provision with a broad view of employment resembling the 1909 Act definition. These courts expand traditional notions of employment by applying the "actual control" test to employment relationships. This test looks to see if the commissioner exercised any control over the creation of the work. If she did, she is an employer and retains

43 See supra note 34 . Senator Cochran has repeatedly attempted to make the definition even less ambiguous by introducing amendments to the work for hire sections of the statute, but these amendments have not been sucessful. See S. 1223, 100th Cong., 1st Sess. (1987); S. 2330, 99th Cong., 2d Sess. (1986); S. 2138, 98th Cong., 1st Sess. (1983); S. 2044, 97th Cong., 2d Sess. (1982). His most recent attempt has not yet come out of committee, but, during the Berne Convention discussions, Senator DeConcini promised that it would be considered next year. See 134 CoNG. REC. S14,560-61 (daily ed. Oct. 5,1988 ) (statement of Sen. Cochran).

1417 U.S.C. § 101 (1982).

15 See supra note 8.

46 See LATMAN, supra note 38 , at 120 n.28 (reporting that the publishers acknowledged that the first subdivision in the definition of work for hire included only salaried employees). Most other commentators agree with this interpretation. See, e.g., Hardy, Copyright Law's Concept of Employment-What Congress Really Intended, 35 J. Copyright Soc'y 210, 210-11 (1988) (arguing that several courts have interpreted the 1976 Act's definition of works made for hire as limiting the meaning of "employment" to "formal employment," which "suggest[s] that Congress intended the 'on special order or commission provision' to be the exclusive for-hire mechanism for independent contractors"); Comment, Employee/Independent Contractor Dichotomy, supra note 9, at 607 ("The legislative history of the 1976 Act seems to indicate that Congress was intent on protecting the rights of independent contractors."); Comment, Commissioned Works, supra note 9, at 1294 ("Because there was no explicit incorporation of prior case law concerning works made for hire, the 1976 Act provided the basis for completely new judicial treatment of commissioned works made for hire."); $c f$. Note, A Misinterpretation, supra note 9, at 651 ("The New Act therefore, has sharply distinguished between employee works prepared within the scope of employment and works prepared by an independent contractor."). 
the copyright because it is a work for hire. This vision of employment raises two problems. First, it substantially reduces the predictability of copyright ownership because of the subjectivity of any test determining creativity. Second, it requires a great deal of understanding of the field in which the creation takes place in order to determine the amount of the commissioner's creative contribution. This determination, quite possibly based on an incorrect understanding of a complex trade such as computer programming, could result in the loss of all of the contractor's rights to the work.

The Fifth, Ninth, and D.C. Circuits take a literal view of the work for hire provisions. This interpretation limits the employment relationship discussed in the first subsection of the work for hire definition to traditional employment, so that a commissioned work can be a work for hire only if it falls into subsection two. This approach provides predictability of copyright ownership, because the test does not depend on the court's subjective evaluation of creativity, and an independent contractor cannot lose copyright ownership unless she agrees in writing.

\section{The Commissioner's Side}

In Aldon Accessories Ltd. v. Spiegel, Inc., ${ }^{47}$ Ginsberg, a principal of the Aldon corporation, decided to produce a line of figures depicting mythological creatures. Ginsberg described his idea for the statuettes to Wado, a Japanese manufacturing company, and Unibright, a Taiwanese firm. Wado and Unibright ultimately manufactured the porcelain and brass figurines, respectively, with Ginsberg supervising the artists. ${ }^{48}$ The court stated that "[ $\mathrm{t}$ ] he gist of [Ginsberg's] testimony was that while he is not an artist and did not do the sketching or sculpting, he actively supervised and directed the work step by step." ${ }^{349}$ Ginsberg registered the copyright for the statuettes in Aldon's name as a "work made for hire."

In mid-1981, Aldon realized that Spiegel was selling brass unicorns identical to Aldon's and sued for copyright infringement. ${ }^{\text {s1 }}$ The court of appeals held that Aldon owned the copyright to the statuettes

47738 F.2d 548 (2d Cir.), cert. denied, 469 U.S. 982 (1984).

18 See Aldon, 738 F.2d at 549-50.

49 Id. at 550. In their article criticizing the Aldon decision, however, Spiegel's attorneys suggested that Ginsberg's role in creating the statues was not very great. See FitzGibbon \& Kendall, The Unicorn in the Courtroom: The Concept of "Supervising and Directing" an Artistic Creation Is a Mythical Beast in the Copyright Law, J. ARTS MGMT. \& L., Fall 1985, at 23, 27-29.

so See Aldon, 738 F.2d at 550 .

si See id. 
because the Taiwanese company's artists were "supervised and directed" by Ginsberg, who was, "in a very real sense, the artistic creator." ${ }^{22}$ Because of Aldon's standing as copyright owner, Aldon could sue Spiegel for infringement. The court then upheld the jury's verdict that Spiegel infringed Aldon's copyright. ${ }^{\mathrm{B3}}$

The Aldon court mentioned little of the legislative history showing Congress's intent to restrict the first section of the statutory definition to traditional employer-employee relationships. Instead, the court said, "Nothing in the 1976 Act or its legislative history indicates that Congress intended to dispense with this prior law applying the concepts of 'employee' and 'scope of employment.' "54 Citing Professor Nimmer, the court continued, "The new Act does not define these key terms, thus suggesting that it is necessary to look at the general law of agency as applied by prior copyright cases in applying subdivision (1) under the new Act."

The court found the indications of change in the Act's legislative history relevant only to the addition of the second section of the work for hire definition. Congress therefore did not intend to erase entirely the influence of the "right to control test" under the 1909 Act. ${ }^{56}$ The court pointed out that, under the 1909 Act, all works created by an independent contractor were presumed to belong to the hiring party "regardless of the presence or absence of direction and supervision by

ธ2 Id. at 553.

53 See id. at 554. The court achieved a just solution as applied to Aldon and Spiegel; Spiegel had stolen the works from Aldon. Denying the Japanese company participation in the copyrights to these statuettes, however, was unfair and unnecessary. See infra notes 136-39 and accompanying text.

s4 Aldon, 738 F.2d at 552.

Bo Id. (citing $1 \mathrm{M}$. Nimmer, Nimmer on Copyright $\S 5.03[\mathrm{~B}][1]$ at $5-12$ to -13 (1983)); see also $1 \mathrm{M}$. NIMMER, NIMMER on Copyright $\$ 5.03$ [B][1][a] at 5-12 to 14 (4th ed. 1987) (discussing who is an employee). As pointed out in Easter Seal Society for Crippled Children \& Adults of Louisiana, Inc. v. Playboy Enterprises., 815 F.2d 323, 330-31 (5th Cir. 1987), cert. denied, 108 S. Ct. 1280 (1988), however, Professor Nimmer does not interpret the 1909 Act case law in the way that the Aldon court said he did. Professor Nimmer saw a distinction between traditional employees and independent contractors even under the 1909 Act. Therefore, when he said that common law construing the 1909 Act should be applied, he meant the common law defining an employee as a traditional employee under agency principles. See id. at 330 n.13. Compare 1 M. NIMMER, supra, at 5-12 to -13 (stating that the right to control test under the 1909 Act is the same as that for an agency relationship) with id. at 5-21 to -22 \& n.60 (stating that, under the 1976 Act, commissioning parties generally have fewer rights than under the 1909 Act).

${ }_{86}$ "Had Congress intended . . . to narrow the type of employment relationships within the work for hire doctrine to include only 'regular' employees, it is unlikely that there would have been no discussion of this change in the legislative history." Aldon, 738 F.2d at 552. But, as set forth earlier, Congress did, in fact, intend to narrow the types of relationships within the doctrine. See supra notes 35-46 and accompanying text. 
the hiring party." ${ }^{157}$ The court attributed the limited changes indicated in the Act's legislative history to Congress's recognition of this injustice. $^{58}$ Thus, Congress only intended to change the work for hire definition by adding the second section preserving rights for independent contractors who performed all of the creative work. ${ }^{59}$ The Second Circuit's interpretation of the Act therefore treats those contractors who contribute less than the entire creative force to a work as employees under subsection one of the Act. ${ }^{\text {Bo }}$

The Second Circuit's myopic analysis of the Act's legislative history places independent contractors in a precarious position. Under its view, contractors must guess whether a court will find that a commissioner has "sufficiently supervised" production of a work before ascertaining copyright ownership. In fields such as computer law in which even "sufficient supervision" may not supersede the contractor's creative effort, the Aldon decision will nonetheless turn independent contractors into "employees," causing them to lose all their rights of copyright ownership while simultaneously denying them the benefits of traditional employment. This situation gives commissioners great incentive to hire contractors, but it does not deal fairly with the contractors. If the commissioner's contribution to the creation of the work were sufficient to consider the work made for hire under Aldon, then the parties should own the work jointly. ${ }^{61}$ The Aldon decision expands the scope of the work for hire doctrine from the Act's prescribed situations of works created either 1) in traditional employment situations or 2) as commissioned works in one of the nine categories with written permission of the contractor, to any situation in which a commissioner has supervised creation of the work. This expansion nullifies the effect of the Act's limitations and defeats Congress's intent as expressed in the legislative history to the Act. ${ }^{62}$

The inequity of the Aldon "actual control" test became more apparent when the Seventh Gircuit applied it in the case of Evans Newton Inc. v. Chicago Systems Software. ${ }^{63}$ Chicago Systems was recommended to Evans Newton as a reliable programming contractor. ${ }^{64}$ The president of Evans Newton prepared the bid guidelines and created the flow charts for new programs, which later became the basis of

${ }^{82}$ Aldon, 738 F.2d at 552.

ss See id.

s8 See id.

${ }^{60}$ See id.

61 See infra notes 113-41 and accompanying text.

62 See supra notes 35-46 and accompanying text.

63793 F.2d 889 (7th Cir.), cert. denied, 479 U.S. 949 (1986).

64 See id. at 891 . 
an informal agreement between the parties stipulating that Chicago Systems would provide the programming and documentation for a set fee. After the programming began, Evans Newton sent Chicago Systems a letter stating that " " $t$ ]he ENI [Evans Newton Inc.] Copyright of this program is fully recognized by Chicago Software Systems [sic]." "6s Although Chicago Systems never responded to this letter, its president signed a statement embodying the letter's terms after the programming was substantially completed. ${ }^{68}$ Evans Newton then registered the program user's manual for copyright as a work made for hire ${ }^{6 z}$ However, it failed to prove that the computer program itself was registered..$^{68}$

In 1980, Chicago Systems began to market a program very similar to the one it created with Evans Newton. ${ }^{69}$ Chicago Systems sold two copies for $\$ 1,200$ apiece and two demonstration disks for less than $\$ 200 .^{70}$ Evans Newton sued Chicago Systems for copyright infringement, asking for damages and an injunction. ${ }^{71}$ The district and appellate courts specifically approved the Aldon decision and held that Chicago Systems had infringed the copyright on the manual. ${ }^{72}$ Although the district court found no evidence that Evans Newton had "sufficiently supervised" the actions of Chicago Systems, the Seventh Circuit affirmed the district court finding that Evans Newton "actually controlled" Chicago Systems. ${ }^{73}$ By giving the copyright to the programs entirely to Evans Newton, which developed only the flow charts, the

${ }^{65}$ Id. at 892 (quoting Letter from Lloyd Ferguson, president of Evans Newton, to Brian Brazda, president of Chicago Systems (Aug. 6, 1979)).

${ }^{68}$ See id. at $892 \&$ n.3.

Bz See id. at 892 .

${ }^{68}$ See id. at 895 n.6.

${ }^{69} \mathrm{See}$ id. at 892.

70 See id.

71 See id. at 891.

72 See id. at 894. The district court dismissed the infringement claim on the software because Evans Newton had not proved registration of it. See id. at 895 n.6. Therefore, the suit involved only infringement of the user's manual.

${ }_{73}$ See id. at 894. The Seventh Circuit affirmed the district court's finding of actual control despite evidence in the record stating that payment was a set fee based on an estimated work time and Evans Newton contributed no programming skills. See id. at 891. As the Fifth Circuit stated:

[T]he "actual control" test . . . can gradually slide into a "right to control" test, just as in the old "work for hire" doctrine the "right to control" test from agency law gradually slid into an almost absolute (though frequently false) presumption that whoever paid for creation of the work had the "right" to control its production. This is not mere pessimistic speculation on our part; we see evidence of this trend already in Evans Newton Inc. v. Chicago Systems Software . . . .

Easter Seal Soc'y for Crippled Children \& Adults of La., Inc. v. Playboy Enters., 815 F.2d 323, 334 (5th Cir. 1987), cert. denied, 108 S. Ct. 1280 (1988). 
court discounted the creative effort expended in programming.

A detailed understanding of the normal trade practices of the field is necessary in order to determine actual control in many of these situations. ${ }^{74}$ If the court incorrectly decides that the commissioner contributed creatively to the work or minimizes the creative input by the contractor, the work will be considered a work for hire and the contractor will retain no copyright to the work. Furthermore, this decision will be made after the work has been created and the parties have contracted for compensation. Therefore, it will be very difficult for the contractor to protect herself monetarily from a potential loss of copyright. The court's apparent misunderstanding of programming and software copyright doctrine caused Chicago Systems to lose all copyright benefits from a work for which they expended a great deal of creative effort. The injustice of the Aldon test is clear here.

The Second and Seventh Circuits align themselves with patrons in the debate over how to further the aims of the copyright clause in the Constitution. Furthermore, they place independent contractors in the uncertain position of relying on a court's evaluation of the creative contribution by commissioners necessary to determine whether the inde-

74 While this understanding is also somewhat necessary in the joint ownership determination, making an uninformed determination in the work for hire context can result in greater injustices. See supra notes $47-73$ and accompanying text. First, the artist loses all copyright to the work made for hire instead of sharing it. Second, the decision to make a work a work for hire under the Aldon interpretation can be totally unexpected by the artist; under joint ownership, the parties must have some sort of intent to create a joint work, thus adding certainty to the transaction. See infra notes 113-16 and accompanying text.

An interesting facet of Evans Newton indicates a possible secondary motivation behind the court's holding. The district court awarded Evans Newton $\$ 16,000$ in damages and the Seventh Circuit affirmed. However, Chicago Systems only made a total of $\$ 1,400$ worth of sales for the program and the manual combined. The court said that Evans Newton

presented sufficient evidence of market penetration, dollar volume, and franchise and dealer fees which indicated that the $\$ 16,000$ award was justified, if not overly conservative. ENI [Evans Newton Inc.] points out that the mere fact that CSS [Chicago Systems Software] was not able to capitalize as it had hoped on its infringement does not prevent the district court from compensating ENI for losses sustained in excess of CSS's profit.

Evans Newton, 793 F.2d at 896 (footnote omitted). It seems remarkable that the sale of two copies of a manual could be responsible for $\$ 16,000$ of economic harm to Evans Newton. It is possible that the court chose this road to distributing ownership rights to compensate Evans Newton for what it felt to be infringement of the programs as well. See id. The fact that, in determining infringement, the district court did not actually determine the similarity of the manuals, but made its finding primarily upon the similarity of the computer programs, supports this theory. See id. at 893 \& n.4. The Seventh Circuit allowed this finding by saying that "the two components had no significant value independent of one another," implying that substantial similarity of the programs would mean substantial similarity of the manuals as well. Id. at 895 . 
pendent contractors will lose the rights to their works. Thus, while encouraging patrons to sponsor artists, these circuits have decreased the incentive for artists to create.

\section{Help for Independent Contractors}

After the Seventh Circuit approved the Aldon doctrine, it seemed that the Second Circuit work for hire doctrine would receive general acceptance among the courts. ${ }^{75}$ However, the Fifth Circuit set its own course in the work for hire field when it decided Easter Seal Society for Crippled Children $\mathcal{E}^{2}$ Adults of Louisiana, Inc. v. Playboy Enterprises. ${ }^{76}$

In this case, an entertainer acting on behalf of the Easter Seal Society collaborated with the New Orleans public television station, WYES, to stage a "Mardi-Gras style" parade. ${ }^{77}$ No mention of copyrights was made during the collaboration. ${ }^{78}$ The entertainer was the "master of ceremonies" and gave a few suggestions to the crew at WYES, but WYES was primarily responsible for the production and direction of the segment. ${ }^{\text {79 }}$ WYES kept a copy of the video footage and used this footage in several other productions. ${ }^{80}$ One producer requesting the tape then spliced it into an "adult" film. This film was shown nationally four times. Some viewers recognized themselves in the film and prompted the Easter Seal Society to sue, among others, WYES and Playboy, one of the film's distributors, for copyright infringement. ${ }^{81}$

The Fifth Circuit found that the first section of the work for hire definition should apply only to traditional employees. The court said that "[c]ourts must use common sense and consider the sort of factors set out in the Restatement to determine whether a given seller is an employee. 'Actual control' . . . [is] relevant, but alone [it] cannot make an otherwise independent contractor into an employee." gave four reasons to support its use of this test:

First . . this interpretation makes sense out of the nine narrow categories in $\S 101(2)$ : they are statutory permission

76 This was despite substantial academic criticism. By 1987, most academic writings discussing Aldon had criticized the decision and advocated a more literal interpretation of the work for hire definition. See supra note 9.

${ }^{76} 815$ F.2d. 323 (5th Cir. 1987), cert. denied, 108 S. Ct. 1280 (1988).

77 See id. at 324.

78 See id.

79 See id.

80 See id.

B1 See id. at 325 .

${ }^{82}$ Id. at 335-36 (citation omitted); see also supra note 8 (quoting the traditional definition of "servant" given in the RESTATEMENT (AGENCY)). 
to allow certain kinds of independent contractors to sign away their authorship to their buyers. Second, this interpretation ties the meaning of "work for hire" to a well-developed doctrine in agency law. . . . Third, this approach gives buyers and sellers the greatest predictability. . . Finally, adopting an agency-law definition of copyright "employment" creates a certain moral symmetry: a buyer is a statutory "author" if and only if he is responsible for the negligent acts of the seller. ${ }^{83}$

Another important part of the Easter Seal opinion introduces joint ownership into the work for hire discussion. Although the court did not decide the issue overtly, ${ }^{84}$ it pointed out that the "actual control" situations that prompted the Aldon court to give work for hire status to a work are probably situations in which joint ownership would be appropriate because of contributions by both parties. ${ }^{\mathbf{8 5}}$

The Easter Seal solution is optimal because it protects the rights of artists while still giving commissioners an economic incentive to sponsor artists. A contractor can create a work for hire only if it falls into one of the nine statutory categories and the contractor signs a written agreement. The nontraditional employee-artist, therefore, cannot lose the copyright to a work when a court later determines that it was created with sufficient supervision by the commissioner. Even if the work lies outside of the statutory categories, however, the commissioner can still obtain the copyright to the work through a transfer of copyright. This transfer requires the author's permission and gives her the right to terminate the transfer after 35 years. ${ }^{86}$ Thus, the Easter Seal decision strikes a balance between encouraging patrons to sponsor creativity and reimbursing artists for their creative work.

The Supreme Court will resolve the work for hire issue in Community for Creative Non-Violence v. Reid (CCNV). ${ }^{87}$ CCNV developed the idea for a statue of a homeless family huddling over a grate with steam coming out of it. It commissioned James Earl Reid to create this statue. ${ }^{88}$ During the design stage, GCNV vetoed a few of the poses he had suggested, and it specified that he use a light material for casting

${ }^{83}$ Id. at 335 . 337.

84 Neither party argued that joint ownership was an option in this case. See id. at

ss See id. at $333,337$.

${ }^{86}$ See infra notes $128-35$ and accompanying text.

87846 F.2d 1485 (D.C. Cir.), cert. granted, 109 S. Ct. 362 (1988).

88 See id. at 1487. 
the statue. ${ }^{89}$ Reid, however, picked the models and did all of the sculpting himself. ${ }^{90} \mathrm{CCNV}$ compensated Reid only for the cost of the materials; he donated his services. ${ }^{\text {ox }}$

After CCNV sent the statue back to Reid for some repairs, it decided to take the sculpture on tour to raise money. Reid opposed the tour because he felt the statue was too fragile to withstand traveling. ${ }^{22}$ $\mathrm{He}$ wanted to recast the statue in a more durable material or make a mold of the statue, but CGNV would not reimburse his expenses. Reid refused to return the statue to CCNV, filed for the copyright to the statue, and planned to take the sculpture on a shorter tour. ${ }^{93}$ CGNV's agent and trustee filed a competing copyright registration certificate in his name. ${ }^{84}$ GCNV then sued Reid for return of the sculpture and declaratory judgment of ownership of the sculpture's copyright. ${ }^{95}$

The district court followed Aldon and found that, because CCNV had sufficiently supervised Reid's work, the sculpture was a work for hire. ${ }^{98}$ The court found that CGNV performed the creative role in the development of the statue ${ }^{97}$ and therefore should have the copyright to it. ${ }^{98}$ The District of Columbia Circuit overturned this holding, however, in favor of the literal interpretation espoused by the Fifth Circuit and "the almost unanimous support [of academic] commentary."

The court's examination of the work for hire definition closely followed the path taken by the Fifth Circuit. The court held succinctly

${ }^{89}$ See Petition for Writ of Certiorari at 4 n.2, 6 n.5, Community for Creative Non-Violence v. Reid, 846 F.2d 1485 (D.C. Cir.), cert. granted, 109 S. Ct. 362 (1988).

${ }^{80}$ See CCNV, 846 F.2d at 1487-88. As Reid said, " Nobody can dictate what I do with my work. My spirit and heart and creativity come from me and from above. It's an opportunity for me to play God, really. It's a life force." "Epstein, Court to Say Who Owns Rights to "Homeless" Sculpture, Philadelphia Inquirer, Nov. 28, 1988, at E1, col. 1, E1, col. 1.

91 See CCNV, 846 F.2d at 1487.

92 See id. at 1488.

93 See id.

94 See id.

9s See id.

${ }^{86}$ See id. at $1491,1493$.

${ }^{97}$ Apparently, the district court felt that sculpting requires little creativity if someone else helps develop the sculpture design.

${ }^{88}$ See Community for Creative Non-Violence v. Reid, 652 F. Supp. 1453, 145657 (D.D.C. 1987), rev'd, 846 F.2d 1485 (D.C. Cir.), cert. granted, 109 S. Ct. 362 (1988).

99 CCNV, 846 F.2d at 1492; see also id. at 1492-93 (citing A. LATMAN, R. Gorman \& J. Ginsburg, Copyright for the Eighties: Cases and Materials (2d ed. 1985)); LATMAN, supra note 38; Litman, supra note 9; Comment, Employeel Independent Contractor Dichotomy, supra note 9; Note, The Freelancer's Trap, supra note 9). 
that Reid was an independent contractor, ${ }^{100}$ that "sculpture surely is not a category of commissioned work enumerated in $\S 101(2)$, and no written agreement existed between CCNV and Reid." 101 The court then pointed to the option of joint ownership as possibly appropriate in this situation. ${ }^{102}$ Because the court found the record insufficient to make such a determination, however, it remanded the case for further factual consideration and development of the "joint work" argument. ${ }^{103}$

In January, the Ninth Circuit essentially sided with the Fifth and D.G. Circuits in Dumas v. Gommerman. ${ }^{104}$ The case involved an artist whose works were commissioned through a gallery for a corporation. ${ }^{105}$ When the artist died, the gallery began to make posters using the commisioned works. ${ }^{106}$ The artist's wife sued for a declaratory judgment regarding copyright ownership and damages, and she won. ${ }^{107}$ The Ninth Circuit reviewed in depth the statutory history of the Act and came to the conclusion that only "formal, salaried employees" are covered by section 101(1) of the Act. ${ }^{108}$ The court went on to say that it thought the Easter Seal test that allowed consideration of the "actual control" factor could lead to results similar to Aldon. ${ }^{109}$ The Ninth Circuit then proposed its own test, which is similar to the agency factors. ${ }^{110}$ By using this test, the court felt that it was restricting the employee definition further than the Fifth Circuit. ${ }^{111}$ In application, however, the two tests will probably yield the same results. ${ }^{112}$ Therefore,

100 See id. at 1494. The court did not spend much time on this issue. In fact, the court disposed of it in a footnote:

Reid, a fine artist, donated his services, worked in his own studio, and personally engaged assistants when he needed them. Creating sculptures was hardly "regular business" for CCNV. Given these matters of fact, see Restatement (Second) of Agency $\S 220$ (1958), we think it evident that Reid was not GCNV's employee . . . .

Id. at 1494 n.11.

101 Id. at 1494.

102 See id. at 1497. "In sum, were it not for the prevailing confusion over the work for hire doctrine, this case . . . might qualify as a textbook example of a jointlyauthored work in which the joint authors co-own the copyright." Id. (footnote omitted). CGNV actually offered joint ownership to Reid before the suit began. See Sculptor and Patron Clash Over Piece, N.Y. Times, Jan. 16, 1989, at A18, col. 1, A18, col. 2.

${ }^{103}$ See CCNV, 846 F.2d at 1496 \& n.14.

104865 F.2d 1093 (9th Cir. 1989).

105 See id. at 1094.

106 See id. at 1095.

107 See id.

108 See id. at 1102.

109 See id. at 1104.

${ }^{110}$ See id. at 1105; see also supra note 8 (providing the Restatement (AGENCY) definition of "servant").

111 See Dumas, 865 F.2d at 1105.

112 The Ninth Circuit stated that the Fifth Gircuit did not limit its definition of 
for purposes of this Comment, their holdings will be treated as the same.

Using either the Aldon or Easter Seal approach, works created in traditional employment relationships become works for hire under subsection one of the Act, and works within the nine statutory categories are works for hire with the contractor's permission. In between lies a grey area containing works created by both the commissioner and the contractor. In order to encourage patronage of creative activities, the Aldon court solved the problem of ownership in such cases by giving the copyright to the commissioner. The Easter Seal, Dumas, and $C C N V$ courts recognized, however, that contractors need incentive to create as well. Denying contractors copyright ownership without notice will not perform this function; therefore, joint ownership offers the best solution for cases falling within the grey area.

\section{JOINT OWNERSHIP OF COPYRIGHT}

\section{A. Statutory Definitions}

The main elements of joint ownership of copyright include the intent to create a joint work, the nature of the contribution by each creator, and the proprietary interests shared among joint authors. Section 101 of the Act defines a joint work as "a work prepared by two or more authors with the intention that their contributions be merged into inseparable or interdependent parts of a unitary whole."113 This definition emphasizes the first two features of joint works: the authors must intend that the work be a joint work, and the contributions must be inseparable or interdependent. Section 201(a) provides that "[t]he authors of a joint work are coowners of copyright in the work."

The House Report on the Act notes that the requisite intent exists "if the authors collaborated with each other, or if each of the authors prepared his or her contribution with the knowledge and intention that it would be merged with the contributions of other authors as inseparable or interdependent parts of a unitary whole." "115 Thus, the inten-

employee to formal, salaried employees because of its consideration of actual control. See id. at 1104. The Fifth Circuit asserted, however, that "[a]ctual control'. . . alone cannot make an otherwise independent contractor into an employee." See Easter Seal, 815 F.2d at 336-37. The difference, then, between the two tests is probably largely semantic. The Ninth Circuit itself acknowledged the subtle difference between the two tests. See Dumas, 865 F.2d at 1104 ("We are in essential agreement with [the Fifth Circuit's] interpretation").

11317 U.S.C. $\S 101$ (1982).

114 Id. § 201(a).

115 House REPORT, supra note 42, at 120, reprinted in 1976 U.S. CODE Cong. 
tion does not have to be to create a specific joint work with a specific artist, but to create part of what will definitely become a joint work. ${ }^{118}$

The House Report gives examples of inseparable and interdependent joint works. Novels or paintings are "inseparable" works. ${ }^{117}$ "Interdependent" works include "a motion picture, opera, or the words and music of a song."118 As Professor Nimmer points out, the differences between the two types of joint works are comparable to the differences between derivative and collective works. ${ }^{119}$

The drafters, however, did not intend that all "interdependent" or "inseparable" works become joint works. If the authors of the interdependent work did not have the requisite intent to create a joint work, the work will most likely become a collective work. ${ }^{120}$ Therefore, the difference between a collective work and an interdependent joint work, and, in the same way, a derivative work and an inseparable joint work, depends on the authors' intent at the time of creation.

\& AdMin. NEws at 5736.

${ }^{116}$ The legislators' definition of intent reflects judicial treatment of intent in cases decided before the Act. See Shapiro, Bernstein \& Co. v. Jerry Vogel Music Co., 161 F.2d 406, 409-10 (2d Cir. 1946) (the "Melancholy Baby Case") (stating that the intent to compose a joint work does not have to be to compose a specific work with a specific coauthor), cert. denied, 331 U.S. 820 (1947); Edward B. Marks Music Corp. v. Jerry Vogel Music Co., 140 F.2d 266, 267 (2d Cir. 1944) ("[I]t makes no difference whether the authors work in concert, or even whether they know each other; it is enough that they mean their contributions to be complementary in the sense that they are to be embodied in a single work to be performed as such.").

117 See House REPORT, supra note 42, at 120, reprinted in 1976 U.S. CoDE Cong. \& ADMin. News at 5736.

118 Id.

119 See 1 M. Nimmer, supra note 55, $\S 6.04$, at 6-11. Professor Nimmer further contends that this difference is insignificant in the United States:

Does it make any difference whether a joint work results from inseparable rather than from interdependent parts? For domestic purposes the distinction is apparently without significance. For foreign purposes, however, there is some greater significance since under most foreign law a joint work results only from a merger of inseparable, but not interdependent parts.

Id. (footnotes omitted).

120 See House Report, supra note 42, at 120, reprinted in 1976 U.S. Code

Cong. \& ADMIN. NEws at 5736. The Report makes this idea clear when it says:

The definition of "joint works" has prompted some concern lest it be construed as converting the authors of previously written works, such as plays, novels, and music, into coauthors of a motion picture in which their work is incorporated. It is true that a motion picture would normally be a joint rather than a collective work with respect to those authors who actually work on the film . . . . On the other hand, although a novelist, playwright, or songwriter may write a work with the hope or expectation that it will be used in a motion picture, this is clearly a case of separate or independent authorship rather than one where the basic intention behind the writing of the work was for motion picture use.

Id. 
Courts have not articulated a specific test for determining the level of contribution by the parties necessary for the work to be considered jointly created; courts have held, however, that the parties' contributions do not have to be quantitatively or qualitatively the same for them to be joint authors. ${ }^{121}$

While coowners could possess a copyright in many ways, the House Report makes it clear that the authors and/or owners are to be tenants in common. Furthermore, any owner of a joint work may license the work without permission of the other owners, as long as she gives the proportional amount of any profits to the other owners. ${ }^{122}$

\section{B. The Practical Difficulties of Joint Ownership}

A discussion of joint ownership merits a brief look at potential practical difficulties which may be encountered in applying this concept to commissioned works. Although problems exist, none is serious enough to prevent joint ownership from becoming a solution in appropriate disputes.

\section{The duty to account}

The duty to account seems straightforward at first glance, but becomes more complicated when one part of the original joint work is used independently for other purposes. For example, if two composers collaborate on a song, one composing the music and the other writing

121 See Maurel v. Smith, 271 F. 211 (2d Cir. 1921). In this case, one of the authors of an operetta, who contributed the story line and a basic outline of the scenes while the other authors wrote the dialogue and music, was nevertheless held to be a joint author. See $i d$. at 215 . A later case that attempted to define the minimum contribution necessary for one to be considered a joint author was Picture Music, Inc. v. Bourne, Inc., 314 F. Supp. 640 (S.D.N.Y. 1970), aff'd on other grounds, 457 F.2d 1213 (2d Cir.), cert. denied, 409 U.S. 997 (1972) (the "Three Little Pigs Case"). The song Three Little Pigs was written for a Walt Disney movie, and Walt Disney owned the copyright under the doctrine of work for hire. Later, Walt Disney assigned the copyright to a company that developed an extended version of the song for release. Two decades after the minor revisions required to lengthen the song, one of the composers involved in the changes sued for a declaration of her part as joint author. See id. at 642-43. The court held that "a more substantial and significant contribution was required to reach a finding of joint ownership." Id. at 647 .

122 See House REPORT, supra note 42, at 121, reprinted in 1976 U.S. Cone Cong. \& ADmin. News at 5736; see also Oddo v. Ries, 743 F.2d 630, 632-33 (9th Gir. 1984) (holding that a joint owner cannot infringe a coowner's copyright, but is subject to a duty to account). Case law before the Act dealt similarily with the rights and duties of joint owners. See Richmond v. Weiner, 353 F.2d 41, 46 (9th Cir. 1965) (holding that a joint owner of copyrights "could not and did not infringe such copyrights”); Donna v. Dodd, Mead \& Co., 374 F. Supp. 429, 430-31 (S.D.N.Y. 1974) (holding that a joint owner may license use of a work subject to a duty to account). 
the lyrics, the two create an interdependent joint work. If, however, in the future, the composer of the music licenses a filmmaker to use only the music in the film's soundtrack, the question arises whether the author of the lyrics is entitled to receive half of the royalties earned under such an agreement. Even though the composers intended for the song to be a joint, interdependent work at the time of creation, in reality, the words and the music can be separated. ${ }^{123}$

This issue, though, should not arise very frequently, because the work at creation was intended to be a joint work and its parts probably will not be used separately. Furthermore, as the court in Edward $B$. Marks Music Corp. v. Jerry Vogel Music Co. ${ }^{124}$ explained in dictum, considering a song that is intended to be a joint work, "[t]he popularity of a song turns upon both the words and the music; the share of each in its success cannot be appraised; they interpenetrate each other as much as the notes of the melody, or separate words of the 'lyric.' "125 Therefore, the music in a song may be desirable as a movie soundtrack because of the popularity of the original song as a whole. The author of the lyrics to the song should be as entitled as the composer to receive an accounting of profits from the music. ${ }^{23}$

\section{Licensing of the joint work}

As emphasized in most joint ownership cases, each author has the right to license the work without the permission of other authors. ${ }^{127}$ This right could cause problems between the joint authors if one author approves of the licensing and the other does not. The common law approach of accounting for profits from the licensing solves one aspect of this problem: at least the dissenting author can receive money from the licensing arrangement. The other solution to this problem is a contract between the coauthors at the time of creation of the work to restrict the licensing right and require approval of all joint authors before the work is licensed. Then, if one of the parties licenses the work without the

${ }^{123}$ This problem may be the reason that many European countries do not give joint authorship to interdependent works. See supra note 119.

124140 F.2d 266 (2d Cir. 1944).

125 Id. at 267.

${ }^{128}$ Accounting of profits also works well in the computer software context. If the flow charts are created by one party and the programming done by another party, with both intending to create a joint work, the work would be an interdependent joint work. Thus, if the flow chart creator wishes to license another programmer to program in another language, even if the first programmer/joint author objected and could not convince the flow chart creator to change her decision, the first programmer would still receive half of the profits made from the flow charts' contribution to the new program.

127 See supra note 122 and accompanying text. 
other's approval, the aggrieved party has a remedy for breach of contract.

\section{Termination of transfers}

Under section 203 of the Act, an "author or, if the author is dead, ... the person or persons who . . . own and are entitled to exercise a total of more than one-half of that author's termination interest"128 may terminate any transfer or licensing of copyrights between thirtyfive and forty years from the execution of the grant. ${ }^{128}$ The provision further states that, if the work is a joint work, majority approval of the termination by the authors, or the persons entitled to exercise their rights, may terminate the transfer or license. ${ }^{130}$ The right to terminate is inalienable and cannot be forfeited through any agreement, including an agreement to make a will. ${ }^{\mathbf{1 3 1}}$ The House Report claims that this provision was included to "safeguard[] authors against unremunerative transfers."132 In spite of these good intentions, however, this language actually can work against the interests of the author. One commentator makes clear the situations in which authors might wish for good reasons to alienate the termination of transfer rights without making it subject to her successors. ${ }^{133}$ However, this commentator also suggests a method to circumvent these problems: create a joint tenancy between the authors at the time of creation of the work..$^{134}$ Joint tenancy would mean that any transfer is automatically only for a life estate. Unfortunately, joint tenancy is not an option available to all joint authors, because a few states have abolished the right of survivorship. ${ }^{135}$

\section{G. Applications of Joint Ownership}

If the court had examined the possibilities of joint ownership in

12817 U.S.C. $\S 203(\mathrm{a})(1)(1982)$.

${ }^{129}$ See id. § 203(a)(3).

130 See id. § 203(a)(1).

131 See id. § 203(a)(5).

132 House REPORT, supra note 42, at 124, reprinted in 1976 U.S. Code CoNG. \& ADMIN. NEwS at 5740 .

${ }_{133}$ See See, Copyright Ownership of Joint Works and Terminations of Transfers, 30 U. KAN. L. REv. 517, 526-28 (1982) (discussing situations in which the author has more trust in the the coauthor to know what to do with the work than in the family members; the author wishes to decrease the possibility of family arguments by placing the termination interest in the hands of someone other than her successors; the author wishes to give more freedom to the coauthor).

${ }^{134}$ See id. at 528-31.

135 See id. at 529 \& n.74 (citing Kentucky, North Carolina, Pennsylvania, Tennessee, Virginia, and West Virginia as states that have abolished the right of survivorship). 
Aldon Accessories Ltd. v. Spiegel, Inc. ${ }^{136}$ it could have protected Aldon from Spiegel's infringing actions without betraying the intent of the Act's drafters. Ginsberg's contribution to the creation of the statuettes satisfies the threshold requirements of joint ownership. As the court said, "While he did not physically wield the sketching pen and sculpting tools, he stood over the artists and artisans at critical stages of the process, telling them exactly what to do. He was, in a very real sense, the artistic creator."137 The artists who actually created the statuettes, however, certainly contributed as well. Therefore, the level of contribution of the parties is sufficient to qualify for a joint work. ${ }^{138}$ Because the two parties collaborated on the creation of a single item, it seems clear that they intended to create a joint work. Both parties must have known that their work would be merged into a "unitary whole." Finally, with Japanese and Taiwanese artisans fleshing out Ginsberg's ideas under Ginsberg's direction, separation of the individual contributions in this case would be impossible. Thus, Ginsberg and the artisans created an inseparable joint work.

Because the statuettes qualify as joint works, Aldon would have standing to sue Spiegel for infringement. Aldon would own the copyright to the porcelain statuettes as a tenant in common with the Japanese manufacturing company and to the brass statuettes with the Taiwanese company. ${ }^{138}$ Thus, Aldon still would receive the damages awarded, subject to payment of the Japanese company's share.

Similarly, joint ownership offers a good solution for the dispute in Community for Creative Non-Violence v. Reid (CCNV). ${ }^{140}$ Both parties contributed substantially to the design of the statuette: GCNV contributed its ideas for the general appearance of the statue, and Reid contributed his artistic talents in creating it. ${ }^{141}$ Because the contributions of both parties to the work were indivisible, the work would qualify as an

${ }^{136} 738$ F.2d 548 (2d Cir.), cert. denied, 469 U.S. 982 (1984); see also supra notes 47-62 and accompanying text (discussing Aldon and its implications).

${ }^{137}$ Aldon, 738 F.2d at 553.

138 As the Fifth Circuit said in Easter Seal Society for Crippled Children \& Adults of Louisiana, Inc. v. Playboy Enterprises, 815 F.2d 323 (5th Cir. 1987), cert. denied, 108 S. Ct. 1280 (1988): "What the court did not appear to bear in mind is that any buyer satisfying a seriously enforced 'actual control' test will ordinarily be a coauthor of the work, entitled to bring and win an action for infringement against a third party." Id. at 333.

239 Under United States law, as employers of the artists, the Japanese company would jointly own the copyright of the porcelain statuettes and the Taiwanese company would jointly own the copyright of the brass statuettes. Because Aldon was the employer of Ginsberg, Aldon would also own the joint copyright to the statuettes. See 17 U.S.C. $§ 101(1)$ (1982).

140846 F.2d 1485 (D.C. Cir.), cert. granted, 109 S. Ct. 362 (1988).

${ }^{141}$ See id. at $1487-88$. 
inseparable joint work. The parties worked in concert to create a single work, so they obviously intended to create a joint work. Any dispute over the statue's tour would be resolved contractually between the parties, but no matter whose choice prevailed, both parties would receive the profits. Therefore, both the nonprofit organization and the artist would benefit from their collaboration. Joint ownership again provides an equitable solution for the grey area of creative contribution causing such difficulty with the work for hire doctrine.

\section{Computer Software as Works Made for Hire and JOINT WORKS}

The difficulty in understanding the intricacies of programming indicates the dangers of depending on a formula that grants software copyright to only one party. The work for hire test proposed by the Second Circuit requires just such a result. On the other hand, the Fifth Circuit test for work for hire is flexible in its distribution of rights, thus allowing for results that accurately reflect the parties' relationship. The Easter Seal ${ }^{\mathbf{1 4 2}}$ test grants full copyright ownership through work for hire to a commissioner only in a traditional employment relationship. Otherwise, the independent contractor will own the work, the contractor will agree in writing to give the copyright ownership to the commissioner, or the parties will own the work jointly. Considering computer software in relation to work for hire and joint ownership shows the benefits of such an objective test in comparison to the subjective Second Circuit analysis.

BPI Systems, Inc. v. Leith ${ }^{143}$ applied the work for hire doctrine to a relationship between a software publisher and an independent contractor. BPI hired Leith to produce twelve programs for an accounts receivable system. ${ }^{144}$ Leith performed all the work at his place of business and was paid by the program. ${ }^{145}$ BPI contributed confidential documents and several copyrighted routines. ${ }^{146}$ Later, Leith created a system similar to the one he had sold to BPI and marketed it himself. BPI sought a preliminary injunction to prevent Leith from selling the new programs or using the routines and confidential information. BPI

142 See Easter Seal Soc'y for Crippled Children \& Adults of La., Inc. v. Playboy Enters., 815 F.2d 323, 325 (5th Cir. 1987), cert. denied, 108 S. Ct. 1280 (1988).

${ }^{143} 532$ F. Supp. 208 (W.D. Tex. 1981).

144 See id. at 210.

148 See id.

${ }^{146}$ See id. Because the routines contributed by plaintiff were created previously for another work, joint ownership was not available as an option for the parties. See supra notes 115-16 and accompanying text (describing the intent required to create joint works). 
claimed that the programs Leith had developed for BPI were works for hire. ${ }^{147}$ The court held that the commissioned programs were not works for hire, because no written agreement between the parties existed to show otherwise. ${ }^{148}$ The court dismissed in one sentence the possibility that Leith was a BPI employee. ${ }^{148}$ On the other hand, it did recognize $\mathrm{BPI}$ 's rights to the routines Leith had used and enjoined their further use. $^{150}$

The Aldon approach would consider Leith controlled by, and therefore an employee of, BPI, because BPI had the right to accept or reject the programs Leith developed and because BPI contributed certain subroutines. Obviously, though, except for BPI's contribution of the copyrighted routines and the idea for an accounts receivable system, Leith did all the creative work. ${ }^{161}$ While BPI certainly should be able to use the programs Leith created, Leith should own the rights to those programs himself. Since Leith's fee only represented the value of a single copy, he would have limited incentive to create the programs. $\mathrm{He}$ could only afford to operate under these circumstances if he received his value as a full-time employee. It is likely, however, that many companies commission programmers to write programs because they cannot afford full-time employees to program for them. The programmers, then, conceivably must sell multiple copies of their work in order to receive the equivalent of a full-time wage. Under the Aldon decision denying such remuneration, however, the creation of computer programs tailored to the needs of smaller companies would decrease, and only large companies would be able to afford computerization. The $A l-$ don analysis quite possibly could slow the growth of small businesses and make it more difficult for them to compete with large companies.

In Evans Newton Inc. v. Chicago Systems Software, ${ }^{162}$ the commissioner did contribute creatively to the programming. Instead of allowing Chicago Systems to share in the copyright ownership of the programs they helped to create, however, the court determined that Evans Newton had made a certain minimum contribution to the project and therefore owned all the rights. Thus, because the court failed to recognize the creativity involved in the programming process, it denied copyright ownership to a major creative force in the program development.

The literal interpretation of work for hire theory in this instance

147 See BPI, 532 F. Supp. at 210.

${ }_{148}$ See id.

149 See id. The court, however, did mention earlier that BPI had no "right to control" Leith. Id.

${ }_{150}$ See id.

151 See id.

162793 F.2d 889 (7th Cir.), cert. denied, 107 U.S. 434 (1986). 
would not have allowed Evans Newton to hold the copyright to the programs or manuals through work for hire. Chicago Systems definitely was not an employee of Evans Newton under agency law. ${ }^{153}$ Second, although the manuals could fall into one of the nine categories of commissioned works, ${ }^{154}$ there was no written agreement making them works for hire. The programs would not fall into any of the commissioned works categories, so the agreement recognizing Evans Newton's rights to them would be irrelevant.

Joint ownership of the programs would have been the most equitable result in this case. The contributions by the parties were interdependent. ${ }^{165}$ The parties intended to create a joint work, even though they created their portions at separate times. ${ }^{158}$ At the time of creation, Chicago Systems and Evans Newton would have owned equal shares, as tenants in common, of the computer system, but Chicago Systems contractually agreed to transfer its rights in the programs to Evans Newton. Evans Newton did not register the programs for copyright, however, and so could not get relief for Chicago Systems' infringement.

The distribution of rights to the manual would be different, because the parties did not contractually address them. The manual was probably a derivative work from the programs, because the manual is dependent on the underlying program. ${ }^{167}$ Chicago Systems would

${ }^{153}$ See id. at 891 (stating that Chicago Systems was an independent contractor); see also supra note 8 (providing the RestATEMENT (AGENCY) definition of "servant").

${ }^{204}$ See 17 U.S.C. \& 101(2). The manual probably would be a "supplementary work" or an "instructional text." See id.

${ }^{185}$ The flow charts contributed by Evans Newton should be copyrightable as an expression of the idea for educational programs. See supra notes 17-19 and accompanying text. The programming done by Chicago Systems was certainly copyrightable. See supra note 15 and accompanying text. Because the programming was dependent on the flow charts, but the flow charts were capable of standing alone, the work would be an interdependent work. See supra note 118 and accompanying text.

${ }_{186}$ In this instance, Evans Newton wrote the flow charts knowing that they would be used to create programs for this specific computer system. See Evans Newton, 793 F.2d at 891. It then contracted with Chicago Systems to create the programs. See id. Thus, the parties satisfied the requirements of co-authorship. Chicago Systems raised the joint ownership option during the proceedings. The court dismissed it out-of-hand, however, by saying the programs could not be jointly owned because they were works for hire. See id. at 893.

The creation of this set of programs would be analogous to the creation of a song: one party created the words and the other party created the music. As often occurs with song-writing, one party writes the words knowing that someone else will set them to music, or a party will write the music knowing that someone else will write the appropriate words. The parties must know at the time of creation of their portions only that the portion will not stand alone and someone else will add to it. See supra notes 115-16 and accompanying text.

${ }^{157}$ The manual is to the program what a film is to the novel it is based on. See 17 U.S.C. $\S \S 101,103$ (1982). The court stated that Chicago Systems created the manual. See Evans Newton, 793 F.2d at 891. 
jointly own the underlying work, at least before the transfer of the program's copyright, and wholly own the material independent of the program required to create the manual. After the transfer of the program, however, Chicago Systems would own only the part of the manual that was new and independent of the program. Furthermore, Chicago Systems would only be able to use this with a license from Evans Newton, the owner of the underlying work. Therefore, Chicago Systems would infringe Evans Newton's potential copyright to the programs every time it sold a manual. This infringement would make Chicago Systems liable to Evans Newton for damages if Evans Newton registered the program for copyright protection.

If Chicago Systems transferred its share of the ownership of the programs to Evans Newton and was liable to Evans Newton for profits from the sale of a manual for a program it did not own, it would hardly profit Chicago Systems to continue marketing this system. ${ }^{158}$ Therefore, the dispute between Evans Newton and Chicago Systems would almost correct itself with a proper distribution of the ownership shares in the programs and manual. Evans Newton would be reimbursed for its lost profits, and Chicago Systems would lose its incentive to continue selling its version of the system. Although this solution does not seem to change the outcome of the Evans Newton dilemma, it does give Chicago Systems new rights. First, Chicago Systems would retain the right to terminate its transfer of the programs. This right would be very valuable, and should be available to Chicago Systems, considering the circumstances under which the transfer was granted. Second, Chicago Systems would own the rights to certain portions of the manual, such as diagrams, that could be used in later works. Third, Chicago Systems would not be discouraged from further programming, because it would not have experienced any unexpected takings of its copyright. Any rights Chicago Systems would lose would have been bargained away. This solution, therefore, also is preferable because it does not change the work for hire doctrine to reach an equitable solution for a particular factual situation.

\section{CONCLUSION}

The analysis provided in this Comment reveals the faults of the Aldon decision. Because Aldon requires investigation into employment situations well outside traditional employer/employee relationships, courts applying its doctrine must learn the trade practices of the specific

${ }^{258}$ This conclusion assumes that Evans Newton registers the programs for copyright protection. 
field in question. For a court to understand what "actual control" is, it must evaluate the degree of control considered "creative" in the trade practices of the community being examined. In the computer software situation, failure to recognize creativity in the act of programming can lead to a court's determination that programmers merely transcribe the underlying flow charts. ${ }^{158}$ Thus, a company believing itself an independent contractor with proprietary interest in its work can suddenly become an employee of its client and lose all its rights to the work.

Such a result could not happen using a literal interpretation of work for hire doctrine, because this approach distinguishes between employees and independent contractors and allows joint ownership to play an increasing role in protecting creative contributions. If the party in question is a traditional employee, the employer owns the work created for it. If, however, the party in question is an independent contractor, the work must satisfy several legislative requirements before it can become a work made for hire. Congress enacted these requirements specifically to protect independent contractors from the unexpected loss of their creative products. Furthermore, if the court determines joint ownership to be appropriate, neither party will lose copyright ownership. The Aldon decision and its progeny destroy the legislative intent to encourage contracting and commissioning through the "carefully balanced compromise" of the work for hire provision. ${ }^{160}$ The literal work for hire interpretation espoused by the Fifth, Ninth, and the D.C. Circuits is the only interpretation that produces equitable and predictable results.

159 Similarly, a court's failure to recognize the creativity required to create a flow chart could give full copyright ownership to a programmer.

${ }^{160}$ HoUSE REPORT, supra note 42, at 121, reprinted in 1976 U.S. Code Cong. \& ADMIN. News at 5736. 
, 